\title{
First record of the non-native fish Poecilia reticulata (Cyprinodontiformes: Poeciliidae), in Chiapas, southern Mexico
}

\author{
Cynthia Paola López-Fuentes ${ }^{1}(D)$, Ernesto Velázquez-Velázquez ${ }^{(i D}$, Manuel de Jesús Anzueto-Calvo ${ }^{2}$, \\ Wilfredo A. Matamoros ${ }^{2}$ \& $\&$ Guillermo Salgado-Maldonado ${ }^{3}$
}

1. Ciencias Biológicas, Instituto de Biología, Universidad de Ciencias y Artes de Chiapas 1a Sur Poniente No. 1460 Col. Centro, C. P. 29000, Tuxtla Gutiérrez, Chiapas, México; pain00746@gmail.com

2. Ciencias Biológicas, Instituto de Ciencias Biológicas, Universidad de Ciencias y Artes de Chiapas, Tuxtla Gutiérrez, Chiapas, México, Programa de posgrado Instituto de Ciencias Biológicas, Universidad de Ciencias y Artes de Chiapas, 1ạ Sur Poniente No. 1460 | Col. Centro, C. P. 29000, Tuxtla Gutiérrez, Chiapas, México; ernesto.velazquez@unicach.mx; manuel.anzueto@unicach.mx; wilmatamoros@yahoo.com

3. Instituto de Biología, Universidad Nacional Autónoma de México, Av. Universidad 3000, Circuito Exterior S/N Delegación Coyoacán, C.P. 04510 Ciudad Universitaria, D.F. México; gsalgado@ib.unam.mx

\author{
Received 19-X-2020 • Corrected 03-III-2021 • Accepted 04-III-2021 \\ DOI: https://doi.org/10.22458/urj.v13i1.3266
}

\begin{abstract}
Introduction: Due to its colors, shape, size, and simplicity of care, the neotropical fish Poecilia reticulata (guppy) is popular in the aquarium trade. It is also valued as mosquito control and is now found in most of the world. Objective: To report its presence in southern Mexico. Methods: Fish were captured with seine nets in a tributary of the Grijalva River, Chiapas, in August 2019, and March 2020. Results: Two hundred and fifty individuals of $P$. reticulata were captured. Conclusion: The species, found in México in 1971, has extended its range to the Grijalva Usumacinta river system.
\end{abstract}

Keywords: Introduced species, exotic species, livebearer fishes.
RESUMEN. "Primer registro del pez introducido Poecilia reticulata (Cyprinodontiformes: Poeciliidae), en Chiapas, sur de México". Introducción: Debido a sus colores, forma, tamaño y simplicidad de cuidado, el pez neotropical Poecilia reticulata (guppy) es popular en el comercio de acuarios. También se valora como control de mosquitos y ahora se encuentra en la mayor parte del mundo. Objetivo: Informar su presencia en el sur de México. Métodos: Se capturaron peces con redes de cerco en un afluente del río Grijalva, Chiapas, en agosto de 2019 y marzo de 2020. Resultados: Se capturaron 250 individuos de $P$. reticulata. Conclusiones: La especie, hallada en México en 1971, ha extendido su ámbito geográfico al sistema fluvial Grijalva Usumacinta.

Palabras clave: Especies introducidas, especies exóticas, peces portadores.

Live-bearing fishes of the family Poeciliidae (Garman, 1895) are a New World family with a widespread natural distributional range that includes South, Middle, North America, and the West Indies (Reznick et al., 2017). Poecilids are small fishes that are recognized by the presence in males of a gonopodium, which is an anal-fin transformed into an intromittent organ used for transferring sperm to the females (Jones et al., 2016). In Central America and southern Mexico, they are the most common and speciose fishes in freshwater systems (Matamoros et al., 2012; Matamoros et al., 2015). The family comprises 29 genera with 275 valid species (Huber, 2019; Fricke et al., 2020), of which Poecilia (Bloch \& Schneider, 1801) is the most specious genus (Huber, 2019; Fricke et al., 2020). Recent molecular phylogenies placed almost all Middle American Poecilia within the subgenus Mollienesia, (Garman, 1895) except for Poecilia caucana (Steindachner, 1880) that is placed in the subgenus Allopoecilia (Steindachner, 1880) (Ho et al., 2016). South American Poecilia such as $P$. reticulata (Peters, 1859), the species herein treated, was assigned to the subgenus Acanthophacelus (Günther, 1866) (Ho et al., 2016). 
Poecilia reticulata is commonly known as guppy and it is one of the most popular aquarium fish in the world (Lucinda \& Van Der Sleen, 2018). It is a small-bodied fish whose males reach up to $50 \mathrm{~mm}$ in standard length whereas females can reach up to $60 \mathrm{~mm}$ in standard length (Froese \& Pauly, 2020). The species naturally occurs in coastal regions of Venezuela, Guyana and Trinidad and Tobago (Magurran, 2005; Deacon et al., 2011). However, due to intentional and nonintentional introductions, its popularity in the aquarium trade and its use for mosquito control (Warbanski et al., 2017), $P$. reticulata now has a global distribution and it is found in all continents except the Antarctica (Fig. 1) (Deacon et al., 2011; Lucinda \& Van Der Sleen, 2018).

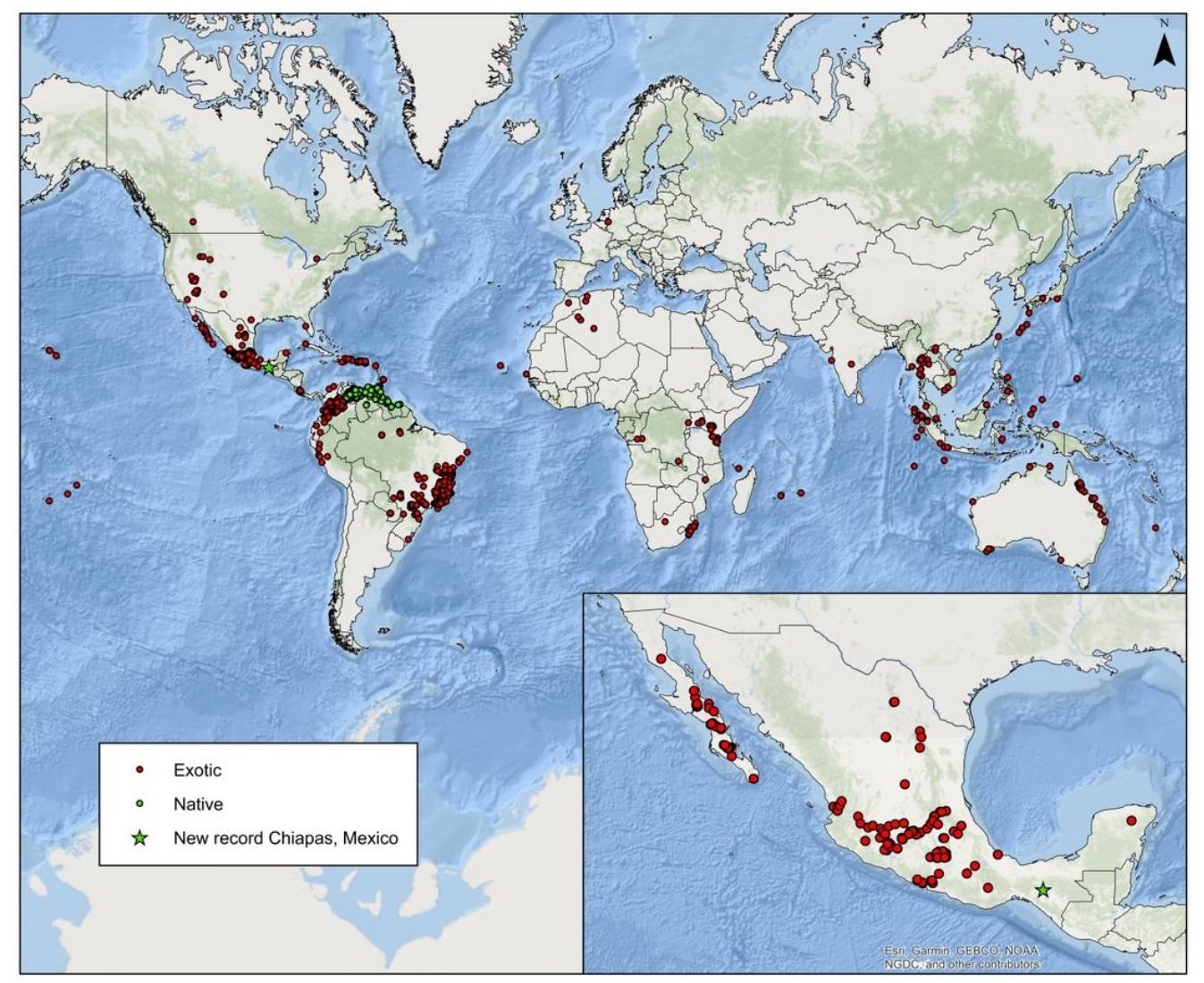

Fig. 1. Distribution localities of Poecilia reticulata worldwide. Right lower corner, collection points in Mexico only.

Poecilia reticulata is currently considered as a highly invasive species (Deacon et al., 2011), capable of modifying native fish communities and ecosystem processes (Fraser \& Lamphere, 2013; Holitzki et al., 2013). Its invasive history suggests, that, once the species arrives at a new environment, life history and biological adaptations such as early reproductive maturity, sperm storage (Meffe \& Snelson, 1989), superfetation (Courtenay \& Meffe, 1989), and air-breathing capacity (Kramer \& Mehegan, 1981; Boschetto et al., 2011), help the species to become well established and sometimes even dominant (Casatti et al., 2009). Although this species is not a top predator capable of directly predating upon native species, its capability of forming large populations may increase the likelihood of out-competing native fishes for food resources and changing rates of nutrient and/or organic-matter cycling, as it has been documented with other invasive species (e.g. Capps \& Flecker, 2013a; 2013b).

In Mexico, P. reticulata was first introduced in 1971 for mosquito control purposes (SalgadoMaldonado \& Rubio-Godoy, 2014). It was registered for the first time in Baja California, currently it 
is reported in streams in Baja California Norte, Baja California Sur and in the Gulf of Mexico (Comisión Nacional para el Conocimiento y Uso de la Biodiversidad [CONABIO], 2017). Although $P$. reticulata is considered a high-risk invasive species at the same level as tilapia (Oreochromis niloticus) (Linnaeus, 1758) (Golubov et al., 2014), the species is still commonly found in the Mexican aquarium trade and several rearing facilities that operate in the country (Devezé-Murillo et al., 2004). In the wild P. reticulata has been collected in at least 109 localities (González et al., 2014) and it has been documented that the river drainages of northwestern Mexico, the species has shown a rapid and successful expansion (Ruiz-Campos et al., 2014). In this paper, we report the occurrence of $P$. reticulata for the first time in a tributary of the Grijalva River in the state of Chiapas, southern Mexico.

The Grijalva River is located in southern Mexico and is part of the Grijalva-Usumacinta River Basin. On August 14th, 2019, and March 12th, 2020, fieldwork was performed in two localities in a small tributary of the Grijalva River near the city of Tuxtla Gutierrez, Chiapas, Mexico. In the two sampling points, we performed a pass with a backpack electro-shocker (DC backpack electrofishing SAMUS RICH P-2000) in a section of river of about $100 \mathrm{~m}$, followed by a pass with a seine in the same river section. After capture, fish were euthanized with an overdose of tricaine methanesulfonate (MS-222), after that, they were placed in a solution of $10 \%$ formaldehyde and transported to the lab. At the laboratory, fish were counted and identified to species, and deposited in the fish collection of the Universidad de Ciencias y Artes de Chiapas.

The two sampled localities are small creeks of $5-7 \mathrm{~m}$ width, with a water depth of $20-30 \mathrm{~cm}$, with riffles, pools and runs. The substrate is dominated by mud, but there were also, rocks, gravel and sand. There is riparian vegetation, but not submerged vegetation or emergent vegetation, canopy cover of $70-80 \%$.

A total of 454 fish were recorded, belonging to five species: Profundulus punctatus (Günther 1866) (10 individuals), Poeciliopsis pleurospilus (Günther 1866) (153 individuals), Poecilia sphenops (Valenciennes 1846) (34 individuals), Astyanax aeneus (Günther 1860) (seven individuals) and Poecilia reticulata (250 individuals). This being the first record of $P$. reticulata in the Grijalva River drainage. UNICACH-MZ-P-7850; August 14, 2019; latitude 16.765813, longitude 93.235263; 120 individuals and UNICACH-MZ-P-7850; March 12, 2020; latitude 16.765897, longitude 93.233472; 130 individuals.

The presence of enlarged and swollen pelvic fins and a fleshy extension of the gonopodium place our specimens in the genus Poecilia (Fig. 2) (Froese \& Pauly, 2020). In order to identify and to distinguished $P$. reticulata from other Poecilia we used a series of meristic and colouration characters as presented by Poeser et al. (2005): (1) polychromatic and polymorphic colouration pattern in males; (2) gonopodial palp extended beyond gonopodium tip; (3) absence of retrorse hook on tip of the gonopodial ray 3a; (4) presence of retrorse hook on tip of gonopodial ray 5 ; (5) gonopodial ray 3 with series of ventral serrae; (6) scales around caudal peduncle 14; and (7) females with 9 anal-fin rays and 6-7 dorsal fin rays. $P$. reticulata shows a conspicuous reticulate pattern along the females flank and lack of a humeral blotch are also useful characters to distinguish the $P$. reticulata from other Poecilia species (Bragança et al., 2020).

Records of $P$. reticulata in Mexico date back to 1971 (Salgado-Maldonado \& Rubio-Godoy, 2014), however, recent checklist from the state of Chiapas did not report $P$. reticulata in freshwater systems (Gómez-González et al., 2015; Velázquez-Velázquez et al., 2016; Soria-Barreto et al., 2018). Herein we report the first record of $P$. reticulata in the Grijalva River Basin. The two localities registered in this study were probably the result of deliberate releases of ornamental fish. The introduction of exotic species is the second greatest threat to biodiversity, after habitat loss (Capdevila-Argüelles et al., 2013). This practice has occurred historically, but it is until recent times that this practice has exploded due to the promotion of trade and the lack of control of it. The 
mitigation and eradication of this practice, which would represent an instrument for the conservation of biodiversity. Therefore, it is essential to establish national strategies that integrate prevention, detection, rapid response, control and eradication of the release of invasive species (National Advisory Committee on Invasive Species, 2010.) One of the crucial activities is the monitoring and the capture of invasive species (Ramírez \& Ramírez, 2017).

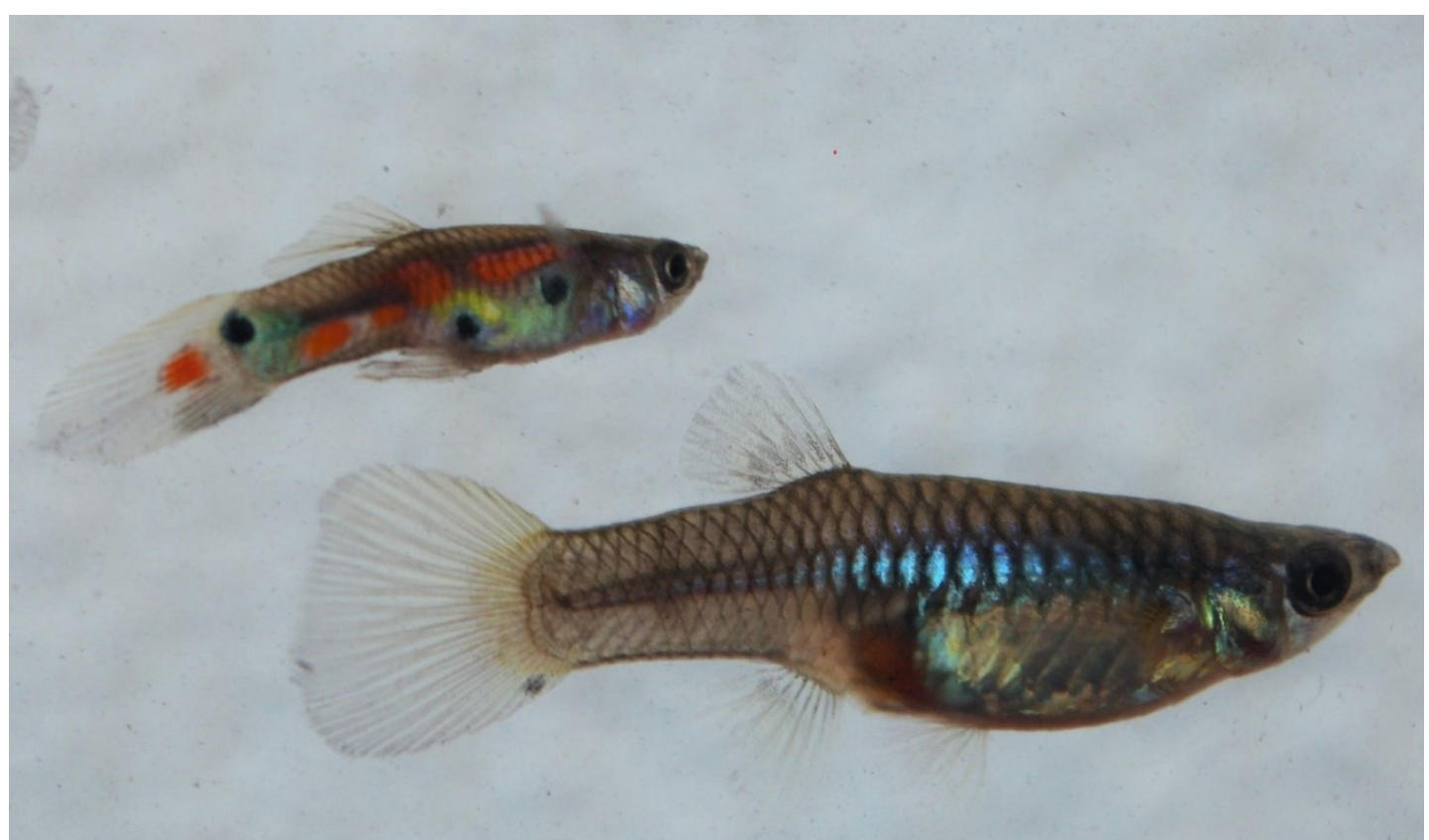

Fig. 2. Male (26,1 mm standard length) and female (49,6 mm standard length) Poecilia reticulata (UNICACH-MZ-P-7850) captured in a tributary of the Grijalva River, near the city of Tuxtla de Gutierrez.

It has been reported that $P$. reticulata can has established ecologically competitive populations in some regions of the country (Ruiz-Campos et al., 2014). Although, that this species is a major threat to native-fish assemblages (Golubov et al., 2014). Poecilia reticulata has still been commercialized in the aquarium trade in Mexico, augmenting this way the possibility of further incrementing the distributional range of the species in Mexican territory. Poecilia reticulata was positively identified because of its conspicuous coloration that does not match any other Chiapas native livebearer fishes. This report is the first record of $P$. reticulata in the state of Chiapas.

\section{ACKNOWLEDGEMENTS}

We are very grateful to Vianey Rodriguez, Ivonne Lopez, and Manuel Mathus for assistance during fieldwork. This study was funded by grants \# CONACYT A-1-S-19959; UNAM DGAPA PAPIIT IN200820 to GS-M.

\section{ETHICAL, CONFLICT OF INTEREST AND FINANCIAL STATEMENTS}

The authors declare that they have fully complied with all pertinent ethical and legal requirements, both during the study and in the production of the manuscript; that there are no conflicts of interest of any kind; that all financial sources are fully and clearly stated in the acknowledgments section; and that they fully agree with the final edited version of the article. A signed document has been filed in the journal archives 
The statement of each author's contribution to the manuscript is as follows: C.P.L.F.: writing of the manuscript, field work and laboratory work. W.A.M., E.V.V. \& M.A.C.: writing of the manuscript and field work.

\section{REFERENCES}

Bragança, P. H., Guimarães, E. C., de Brito, P. S., \& Polivanov Ottoni, F. (2020). On the natural occurrence of Poecilia reticulata Peters, 1859 (Cyprinodontiformes: Poeciliidae). Cybium, 44(4), 309-316. https://doi.org/10.26028/cybium/2020-444-002

Boschetto, C., Gasparini, C., \& Pilastro, A. (2011). Sperm number and velocity affect sperm competition success in the guppy (Poecilia reticulata). Behavioral Ecology and Sociobiology, 65(4), 813-821. https://doi.org/10.1007/s00265010-1085-y

Capdevila-Argüelles, L., Zilletti, B., \& Suárez-Álvarez, V. A. (2013). Causes of biodiversity loss: Invasive Alien Species. Memorias de la Real Sociedad Española de Historia Natural, 10(2a), 55-75. http://www.rsehn.es/cont/publis/boletines/192.pdf

Capps, K. A., \& Flecker, A. S. (2013a). Invasive aquarium fish transform ecosystem nutrient dynamics. Proceedings of the Royal Society B: Biological Sciences, 280(1769), 20131520. https://doi.org/10.1098/rspb.2013.1520

Capps, K. A., \& Flecker, A. S. (2013b). Invasive Fishes Generate Biogeochemical Hotspots in a Nutrient-Limited System. PLOS ONE, 8(1), e54093. https://doi.org/10.1371/journal.pone.0054093

Casatti, L., de Paula-Ferreira, C., \& Carvalho, F. R. (2009). Grass-dominated stream sites exhibit low fish species diversity and dominance by guppies: an assessment of two tropical pasture river basins. Hydrobiologia, 632(1), 273-283. https://doi.org/10.1007/s10750-009-9849-y

Comisión Nacional para el Conocimiento y Uso de la Biodiversidad (CONABIO). (2017). Evaluación rápida de invasividad de Poecilia reticulata. Sistema de información sobre especies invasoras en México. Comisión Nacional para el Conocimiento y Uso de la Biodiversidad. México https://enciclovida.mx/pdfs/exoticas_invasoras/Poecilia\%20reticulata.pdf

Courtenay, W. R., \& Meffe, G. (1989). Small fishes in strange places: a review of introduced poeciliids. In G. Meffe \& F. Snelson (Eds.), Ecology and evolution of livebearing fishes (Poeciliidae). (pp. 319-331). Prentice-Hall.

Deacon, A. E., Ramnarine, I. W., \& Magurran, A. E. (2011). How Reproductive Ecology Contributes to the Spread of a Globally Invasive Fish. PLOS ONE, 6(9), e24416. https://doi.org/10.1371/journal.pone.0024416

Devezé-Murillo, P., Reta-Mendiola, J. L., \& Sánchez-Luna, B. (2004). Cultivo de Poecilia reticulata (Pisces:Poecilidae) en cuerpos de agua tropicales, Veracruz, México. Revista de Biología Tropical, 54(4), 951-958. https://www.scielo.sa.cr/scielo.php?script=sci_arttext\&pid=S0034-77442004000400017

Fraser, D., \& Lamphere, B. (2013). Experimental evaluation of predation as a facilitator of invasion success in a stream fish. Ecology, 94(3), 640-649. https://doi.org/10.1890/12-0803.1

Fricke, R., Eschmeyer, W., \& Fong, J. (2020). Eschmeyer's catalog of fishes: Species by family/subfamily. http://researcharchive.calacademy.org/research/ichthyology/catalog/SpeciesByFamily.asp

Froese, R., \& Pauly, D. (2020) FishBase. https://www.fishbase.de/summary/Poecilia-reticulata.html

Golubov, J., Mandujano, M. C., Guerrero-Eloísa, S., Mendoza, R., Koleff P., González, A. I., Barrios, Y., \& Born-Schmidt, G. (2014). Análisis multicriterio para ponderar el riesgo de las especies invasoras. In: R. Mendoza \& P. Koleff (Eds.), Especies acuáticas invasoras en México. (pp. 123-133). Comisión Nacional para el Conocimiento y Uso de la Biodiversidad. 
Gómez-González, A. E., Velázquez-Velázquez, E., Anzueto-Calvo, M. D. J., \& Maza-Cruz, M. F. (2015). Fishes of the Grijalva River basin of Mexico and Guatemala. Check List, 11(5), 1726. https://doi.org/10.15560/11.1726

González, A. I., Barrios, Y., Born-Schmidt, G., \& Koleff, P. (2014). El sistema de información sobre especies invasoras. In R. Mendoza \& P. Koleff (Eds.), Especies acuáticas invasoras en México. (pp. 95-112). Comisión Nacional para el Conocimiento y Uso de la Biodiversidad.

Ho, A. L. F. C., Pruett, C. L., \& Lin, J. (2016). Phylogeny and biogeography of Poecilia (Cyprinodontiformes: Poeciliinae) across Central and South America based on mitochondrial and nuclear DNA markers. Molecular Phylogenetics and Evolution, 101, 32-45. https://doi.org/10.1016/j.ympev.2016.04.032

Holitzki, T.M., MacKenzie, R. A., Wiegner, T. N., \& McDermid, K. J. (2013). Differences in ecological structure, function, and native species abundance between native and invaded Hawaiian streams. Ecological Applications, 23(6), 13671383. https://doi.org/10.1890/12-0529.1

Huber, J. H. (2019). A nomenclatural and systematic Analysis of livebearing Cyprinodontiformes (Acanthopterygii: Anablepsinae, Goodeinae, Poeciliidae). http://www.killi-data.org/series-kd.php

Jones, J. C., Fruciano, C., Keller, A., Schartl, M., \& Meyer, A. (2016). Evolution of the elaborate male intromittent organ of Xiphophorus fishes. Ecology and Evolution, 6(20), 7207-7220. https://doi.org/10.1002/ece3.2396

Kramer, D. L., \& Mehegan, J. P. (1981). Aquatic surface respiration, an adaptive response to hypoxia in the guppy, Poecilia reticulata (Pisces, Poeciliidae). Environmental Biology of Fishes, 6(3-4), 299-313. https://doi.org/10.1007/bf00005759

Lucinda, P. H. F., \& Van der Sleen, P. (2018). Family Poeciliidae-Livebearers. In P. Van der Sleen \& J. S. Albert (Eds.), Field Guide to the Fishes of the Amazon, Orinoco \& Guianas. (pp. 346-350). Princeton University Press.

National Advisory Committee on Invasive Species. (2010). National strategy on invasive species in Mexico, prevention, control and eradication. Comisión Nacional para el Conocimiento y Uso de la Biodiversidad, Comisión Nacional de Áreas Protegidas, Secretaría de Medio Ambiente y Recursos Naturales. México. https://www.cabi.org/Uploads/isc/caribbean-legislation/mexico-invasive-species-dec-2010.pdf

Magurran, A. E. (2005). Evolutionary Ecology: The Trinidadian Guppy. Oxford University Press.

Matamoros, W. A., Kreiser, B. R., \& Schaefer, J. F. (2012). A delineation of Nuclear Middle America biogeographical provinces based on river basin faunistic similarities. Reviews in Fish Biology and Fisheries, 22(1), 351-365. https://doi.org/10.1007/s11160-011-9232-8

Matamoros, W. A., McMahan, C. D., Chakrabarty, P., Albert, J. S., \& Schaefer, J. F. (2015). Derivation of the freshwater fish fauna of Central America revisited: Myers's hypothesis in the twenty-first century. Cladistics, 31(2), 177-188. https://doi.org/10.1111/cla.12081

Meffe, G. K., \& Snelson, F. F. (1989). An ecological overview of Poeciliid fishes. In G. K. Meffe (Ed.), Ecology and evolution of livebearing fishes (Poeciliidae) (pp. 13-31). Prentice Hall.

Poeser, F. N., Kempkes, M., \& Isbrücker, I. J. H. (2005). Description of Poecilia (Acanthophacelus) wingei n. sp. from the Paría Peninsula, Venezuela, including notes on Acanthophacelus Eigenmann, 1907 and other subgenera of Poecilia Bloch and Schneider, 1801 (Teleostei, Cyprinodontiformes, Poeciliidae). Contributions to Zoology, 74(1-2), 97-115. https://doi.org/10.1163/18759866-0740102007

Ramírez, H., \& Ramírez, J. G. (2017). Estudio para identificar las vías de introducción de la enredadera tripa de zopilote (Cissus verticillata), carrizo (Arundo donax) y zacate buffel (Cenchrus ciliaris) en la RBMNN y su área de influencia. https://www.biodiversidad.gob.mx/media/1/especies/Invasoras/files/comp2/3_Vias_Introduccion_EEI_RBMaris mas.pdf

Reznick, D. N., Furness, A. I., Meredith, R. W., \& Springer, M. S. (2017). The origin and biogeographic diversification of fishes in the family Poeciliidae. PLOS ONE, 12(3), e0172546. https://doi.org/10.1371/journal.pone.0172546 
Ruiz-Campos, G., Varela-Romero, A., Sánchez-Gonzales, S., Camarena-Rosales, F., Maeda-Martínez, A., González-Acosta, A. F., \& Delgadillo-Rodríguez, J. (2014). Peces invasores en el noroeste de México. In R. Mendoza \& P. Koleff (Eds.), Especies acuáticas invasoras en México. (pp. 375-399). Comisión nacional para el conocimiento y Uso de la Biodiversidad.

Salgado-Maldonado, G., \& Rubio-Godoy, M. (2014). Helmintos parásitos de peces de agua dulce introducidos. In R. Mendoza \& P. Koleff (Eds.), Especies acuáticas invasoras en México. (pp. 269-285). Comisión Nacional para el Conocimiento y Uso de la Biodiversidad.

Soria-Barreto, M., González-Díaz, A. A., Castillo-Domínguez, A., Álvarez-Pliego, N., \& Rodiles-Hernández, R. (2018). Diversidad íctica en la cuenca del Usumacinta, México. Revista Mexicana de Biodiversidad, 89(supl. 2018), 100117. https://doi.org/10.22201/ib.20078706e.2018.0.2462

Velázquez-Velázquez, E., López-Vila, J. M., Gómez-González, A. E., Romero-Berny, E. I., Lievano-Trujillo, J. L., \& Matamoros, W. A. (2016). Checklist of the continental fishes of the state of Chiapas, Mexico, and their distribution. ZooKeys, 632, 99-120. https://doi.org/10.3897/zookeys.632.9747

Warbanski, M. L., Marques, P., Frauendorf, T. C., Phillip, D. A. T., \& El-Sabaawi, R. W. (2017). Implications of guppy (Poecilia reticulata) life-history phenotype for mosquito control. Ecology and Evolution, 7(10), 3324-3334. https://doi.org/10.1002/ece3.2666

Edited by Melissa Garro Garita. 